\title{
Krabbamein í eistum á Íslandi 2000-2009: Nýgengi og lífshorfur
}

\section{Andri Wilberg \\ Orrason ${ }^{1}$ \\ læknanemi}

Bjarni A.

Agnarsson $^{1,2}$

meinafræðingur

\section{Guð̆mundur}

Geirsson $^{1,3}$

pvagfæraskurðlæknir

Helgi H. Helgason ${ }^{4}$, lyf- og krabbameinslæknir

Tómas

Guðbjartsson ${ }^{1,3}$ skurðlæknir

Lykilorð: Eistnakrabbamein sáđfrumukrabbamein, ekkisáđfrumukrabbamein, nýgengi, lífshorfur, meðferð.

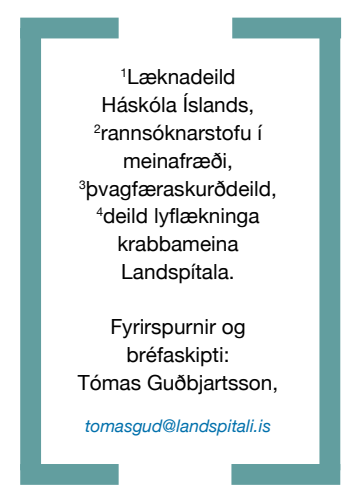

\section{Ágrip}

Inngangur: Á síðustu áratugum hafa lífshorfur sjúklinga með eistnakrabbamein batnað umtalsvert, aðallega vegna tilkomu öflugra krabbameinslyfja. Markmið rannsóknarinnar var að kanna nýgengi, stigun og lífshorfur sjúklinga síðastliðin 10 ár og bera saman við eldri rannsóknir.

Efniviður og aðferðir: Rannsóknin er afturskyggn og nær til allra íslenskra karla sem greindust 20002009. Farið var yfir meinafræðisvör og æxlin stiguð með kerfi Boden-Gibb. Heildarlífshorfur voru reiknaðar og borin saman sáðfrumukrabbamein (SFK) og ekki-sáðfrumukrabbamein (E-SFK).

Niðurstöður: Alls greindust 97 karlar og var aldursstaðlað nýgengi 5,9/100.000 karla á ári. Hlutfall SFK og E-SFK var jafnt, en meðalaldur við greiningu var 35,6 \pm 12,0 ár (bil 15-76 ) og var 11,5 árum hærri fyrir SFK en E-SFK. Einkenni og tímalengd einkenna voru hins vegar svipuð, einnig meðalstærð æxlanna $(4,0 \mathrm{~cm})$ sem hélst óbreytt á rannsóknartímabilinu. Flest æxlanna voru á stigi I, eða 78,4\%, 13,4\% á stigi II og $8,2 \%$ á stigum III-IV. SFK greindust á marktækt lægri stigum samanborið við E-SFK (91,7 sbr. $65,3 \%$ á stigi I; $p=0,003$ ). Engin fjarmeinvörp greindust hjá sjúklingum með SFK en hjá átta sjúklingum með E-SFK. Fjórir sjúklingar létust á rannsóknartímabilinu, tveir úr E-SFK en enginn úr SFK. Fimm ára lífshorfur fyrir allan hópinn voru $95,1 \%$.

Ályktun: Miðað við nágrannalönd er nýgengi eistnakrabbameins á Íslandi í meðallagi og hefur haldist stöðugt síðustu tvo áratugi. Á sama tímabili hefur hlutfall sjúklinga með staðbundinn sjúkdóm (stig I) lítið breyst og stærð æxlanna sömuleiðis. Lífshorfur hér á landi hafa haldist mjög góðar síðustu áratugi og eru með pví hæsta sem pekkist.

\section{Inngangur}

Krabbamein í eistum eru langoftast upprunnin í kímfrumum eistans og skiptast í tvo hópa; sáðfrumukrabbamein (SFK) og ekki-sáðfrumukrabbamein (E-SFK). Petta er algengasta krabbameinið sem greinist í ungum karlmönnum á
Vesturlöndum og hefur svo einnig verið hér á landi. ${ }^{1}$ Engu að síður eru eistnakrabbamein aðeins $1,4 \%$ allra illkynja æxla sem greinast í körlum á Íslandi. ${ }^{2}$ Líkt og annars staðar á Vesturlöndum hefur nýgengi sjúkdómsins hér á landi farið vaxandi og á Norðurlöndunum er nýgengi með pví hæsta sem pekkist á heimsvísu, sérstaklega í Danmörku og Noregi. ${ }^{1,3}$ Orsök sjúkdómsins er ekki pekkt en ýmsir áhættupættir eru pó vel skilgreindir, svo sem launeista (cryptorchidism), fjölskyldusaga, rýrt eista (atrophic testis) og saga um ófrjósemi. ${ }^{4}$ Nýgengi er mismunandi á milli kynpátta, til dæmis er nýgengi fimmfalt hærra hjá Bandaríkjamönnum af afrískum uppruna en hvítum. ${ }^{5}$ Umhverfispættir virðast einnig skipta miklu máli, enda pótt fæstir pessara pátta séu pekktir í dag. Petta styðja danskar rannsóknir á innflytjendum af annarri kynslóð. Hjá peim er nýgengi eistnakrabbameins sambærilegt og hjá innfæddum Dönum og mun hærra en nýgengi í löndunum sem peir komu frá. ${ }^{6}$

Algengasta einkenni eistnakrabbameins er sársaukalaus fyrirferð í pung, en verkur eða bólga í eistanu eru önnur algeng einkenni. Sum pessara æxla geta valdið brjóstastækkun og spennu í geirvörtum vegna framleiðslu á hormóninu $\beta$-hCG (beta human chorionic gonadotrophin). ${ }^{7}$ Einkenni geta einnig stafað frá eitilmeinvörpum í aftanskinurými, eða frá fjarmeinvörpum í miðmæti og lungum. ${ }^{8}$ Við skoðun á eistanu er yfirborð pess oft óreglulegt en með ómskoðun má greina fyrirferðina betur. Einnig eru mældir æxlisvísar í blóđi, meðal annars alfa-fetóprótein (AFP), $\beta$-hCG og laktat-dehýdrógenasi (LD). Styrkur æxlisvísa í blóði getur gefið vísbendingu um vefjagerð krabbameinsins, útbreiðslu pess og lífshorfur. Peir eru pví mældir fyrir og eftir skurðaðgerð, meðan á lyfjameðferð stendur og við eftirlit.

Meðferð eistnakrabbameins felst í að fjarlægja eistað með skurðaðgerð og er komist að eistanu gegnum nára og hnýtt fyrir kólf (funiculus) eistans. Frekari meðferð ræðst síðan af útbreiðslu (stigun) sjúkdómsins og felst pá oft í meðferð með krabbameinslyfjum og/eða geislum. Reynt er að fjarlægja meinvörp sem svara illa lyfjameðferð 


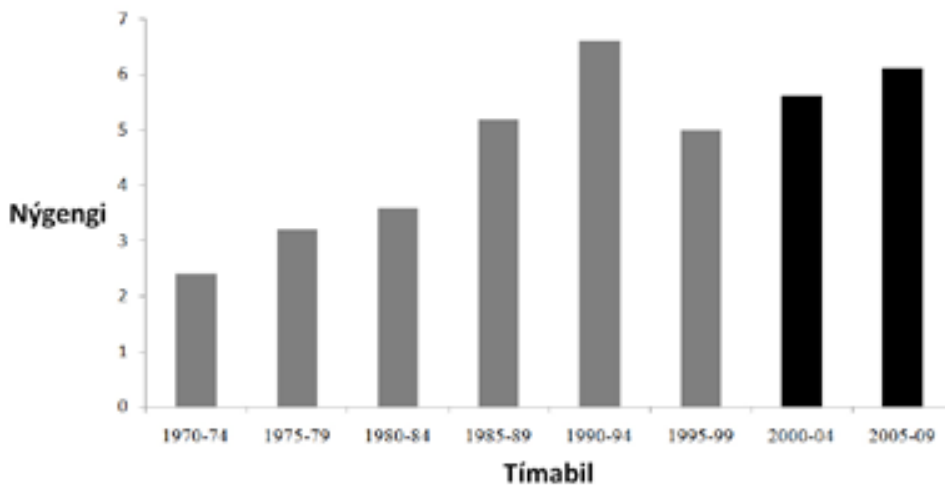

Mynd 1. Aldursstaðlað nýgengi eistnakrabbameins á hverja 100.000 karla á Íslandi á fimm ára tímabilum frá 1970 til 2009. Upplýsingar um tímabilið 1970-1999 eru fengnar úr heimild nr. 9, en tímabil pessarar rannsóknar er merkt með svörtum lit.

með skurðaðgerð og eru pað oftast meinvörp í aftanskinueitlum.

Lífshorfur sjúklinga með eistnakrabbamein hafa batnað verulega síðustu áratugi. ${ }^{9} \mathrm{Er}$ pað helst að pakka fjöllyfjameðferð með cisplatínum en hér á landi var byrjað að nota slíka meðferð tiltölulega snemma eftir uppgötvun peirra, eða í lok áttunda áratugarins. ${ }^{9,10}$ Samkvæmt erlendum rannsóknum má nú gera ráð fyrir lækningu næstum allra sem greinast með staðbundið eistnakrabbamein og hjá rúmlega $90 \%$ sjúklinga með útbreitt eistnakrabbamein. ${ }^{11}$

Gerðar hafa verið nokkrar klínískar rannsóknir á eistnakrabbameini hér á landi. Í Læknablaðinu hafa birst rannsóknir á SFK ${ }^{12}$ og E-SFK ${ }^{13}$ tilfellum sem greindust á tímabilinu frá 1970 til 1990. Einnig hefur birst ítarleg úttekt erlendis á vefjagerð pessara æxla ${ }^{10}$ og lífshorfum karla sem greindust 1970-2002. ${ }^{9}$ Engin pessara rannsókna hefur nád til tilfella sem greinst hafa eftir 2002, en margt bendir til pess að vitund og pekking almennings hafi aukist vegna meiri umræðu um sjúkdóminn. Spurningin er síðan hvort petta hafi leitt til pess að karlar greinist fyrr með eistnakrabbamein og hvort lífshorfur peirra hafi vænkast enn frekar.

Markmið pessarar rannsóknar var pví að rannsaka karla sem greindust hér á landi á tíma-

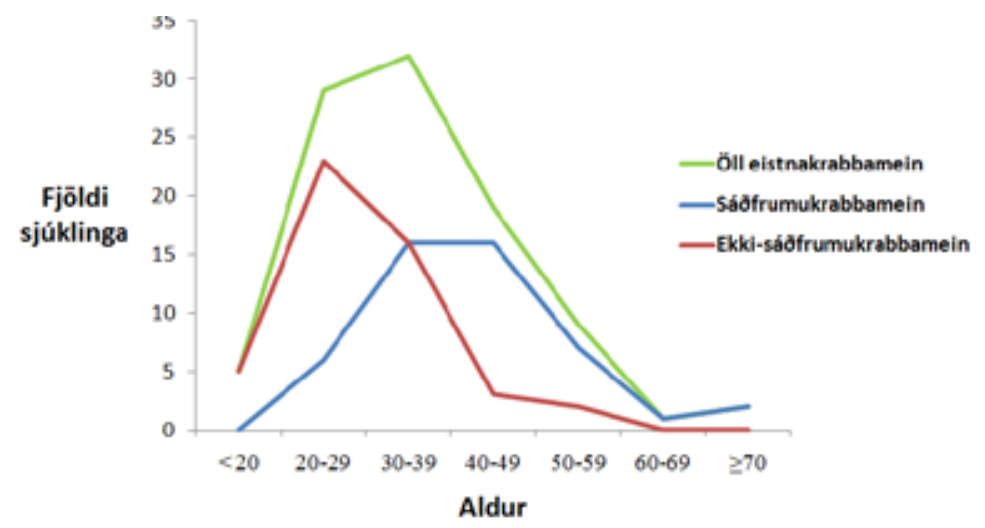

Mynd 2. Aldursdreifing sjúklinga með eistnakrabbmein á Íslandi 2000-2009. Sádfrumukrabbamein og ekki-sádfrumukrabbamein eru sýnd hoort um sig og saman. bilinu 2000-2009 með sérstakri áherslu á nýgengi, stigun og lífshorfur og bera saman við niðurstöður eldri rannsókna.

\section{Efniviður og að̆ferŏir}

Rannsóknin er afturskyggn og nær til allra íslenskra karla sem greindust með eistnakrabbamein á Íslandi frá 1. janúar 2000 til 31. desember 2009. Flokkunarkerfi Alpjóðaheilbrigðismálastofnunarinnar fyrir illkynja æxli í eistum var haft til hliðsjónar við vefjafræðilega flokkun æxlanna (ICD-10, C62). Alls greindust 102 æxli í eistum á pessu tímabili og voru 97 peirra upprunnin í kímfrumum eistans en fimm voru eitilkrabbamein (lymphoma) og voru pau tilfelli útilokuð frá rannsókninni. Blönduð æxli af SFK og E-SFK voru flokkuð sem E-SFK.

Sjúklingar voru fundnir með leit í tveimur aðskildum skrám, í gagnagrunni Rannsóknarstofu Landspítala í meinafræði og í Krabbameinsskrá Krabbameinsfélags Íslands. ${ }^{2}$ Reiknað var út aldursstaðlað nýgengi á rannsóknartímabilinu, en upplýsingar um mannfjölda fengust frá Hagstofu Íslands. Klínískar upplýsingar fengust úr sjúkraskrám, meinafræðisvörum og rafrænu sögukerfi Landspítala. Einnig fengust upplýsingar úr sjúkraskrám sjúkrahúsanna á Akureyri, Akranesi og Heilbrigðisstofnun Suðurnesja.

Skráðar voru tæplega 40 breytur í tölvuforritið Excel, meðal annars með hvaða hætti sjúklingar greindust, helstu einkenni og hversu langur tími leið frá pví fyrstu einkenni gerðu vart við sig uns greining var gerð. Einnig voru skráðar mælingar á æxlisvísum, vefjagerð æxlis, stærð, staðsetning, meinvörp og vöxtur í æðar. Upplýsingum var safnað saman og pær skoðaðar með aðstoð tölvuforritsins Excel. Sjúklingar voru síðan stigaðir samkvæmt kerfi Boden- Gibb ${ }^{14}$ en pað hefur verið notað lengst af hér á landi og auðveldar pví samanburð við eldri rannsóknir. Sjúklingar voru einnig stigaðir með TNM-stigunarkerfinu (TNM: tumor, nodes, metastases: æxli, eitlar, meinvörp) en pær upplýsingar eru ekki gefnar upp.

Rannsóknartímabilinu var skipt í tvö fimm ára tímabil og pau borin saman. Einnig voru niðurstöður bornar saman við eldri rannsóknir á eistnakrabbameini á Íslandi sem áður hafa birst í Læknablaðinu og taka til tilfella sem greindust á árunum 1970 til 1999.9,10

Ómskoðun af eistanu var framkvæmd hjá öllum sjúklingum nema einum. Fyrir og eftir aðgerð var einnig gerð lungnamynd og tölvusneiðmyndir af kviðar- og brjóstholi. Einnig voru mældir æxlisvísar (AFP og $\beta$-hCG), i flestum tilvikum fyrir og eftir aðgerð. Í pessari rannsókn 
var ákveðið að sleppa blóðmæligildum fyrir LD pví slíkar mælingar hafa ekki verið gerðar með skipulögðum hætti hér á landi.

Við tölfræðilega útreikninga var beitt kíkvaðratsprófi (hlutfallsbreytur) og t-prófi við samanburð á hópum (samfelldar breytur). Heildarlífshorfur (overall survival) og sjúkdóma-sértækar lífshorfur (cancer specific survival) sjúklinga voru reiknaðar með Kaplan-Meier aðferð og miðast útreikningar við 1. maí 2010. Við samanburð á lífshorfum hópa var notast við log-rank próf. Tölfræðileg marktækni miðast við p-gildi <0,05.

Öll tilskilin leyfi lágu fyrir áđur en rannsóknin hófst, frá Persónuvernd, Vísindasiðanefnd og frá framkvæmdastjóra lækninga á Landspítala.

\section{Niðurstöður}

Alls greindust 97 karlar með kímfrumukrabbamein í eistum á rannsóknartímabilinu sem náđi yfir 10 ár; 48 SFK (49,5\%) og 49 E-SFK (50,5\%). Öll æxlin greindust í pung nema hjá einum sjúklingi par sem eistað var staðsett í kviðarholi. Ekki var marktækur munur á fjölda æxla í hægra og vinstra eista ( 46,4 vs. $53,6 \%, p=0,39)$, en enginn greindist með æxli í báðum eistum.

Aldursstaðlað nýgengi fyrir allan hópinn var 5,9 á hverja 100.000 karla á rannsóknartímabilinu, en nýgengi E-SFK hækkaði úr 2,7 1́ 3,6 en nýgengi SFK lækkaði úr 3,0 í 2,5 á fyrra og seinna fimm ára tímabili rannsóknarinnar $(\mathrm{p}=0,09)$.

Á mynd 1 er sýnt hvernig nýgengi eistnakrabbameins hefur breyst hér á landi frá 1970, par á meðal á síðustu 10 árunum sem pessi rannsókn tók til. Lægst var nýgengið 1970-1974, eða 2,4/100.000 karla á ári en hæst 1990-1994 pegar pað var 6,6/100.000 karla á ári. Síðan virðist nýgengið hafa haldist stöðugt hér á landi.

Aldursdreifing er sýnd á mynd 2 en meðalaldur við greiningu var 35,6 \pm 12,0 og aldursbil 15-76 ár. Sjúklingar með SFK voru að meðaltali 11,5 árum eldri við greiningu samanborið við sjúklinga með E-SFK (41,6 sbr. 30,1 ár; $\mathrm{p}<0,0001)$.

Af pekktum áhættupáttum reyndust átta sjúklingar $(8,2 \%)$ vera með fyrri sögu um launeista og höfðu allir nema einn gengist undir aðgerð vegna pess. Einn sjúklingur (1,0\%) var með pekkta fjölskyldusögu en faðir hans hafði greinst með eistnakrabbamein.

Allir sjúklingarnir 97 greindust vegna einkenna eistnakrabbameins. Fyrirferð í eista $(94,8 \%)$ og verkir $(43,3 \%)$ voru langalgengustu einkennin en 55 sjúklingar höfðu fyrirferð án verkja (56,7\%). Sjö höfðu einkenni meinvarpa, oftast kviðverki sem raktir voru til eitilmeinvarpa í aftanskinurými. Önnur einkenni meinvarpa voru hósti og tak-
Tafla I. Vefjafræðileg flokkun kímfrumuæxla í eistum á Íslandi 2000-2009. Um tveir priðju ekki-sáðfrumukrabbameina voru blönduð æxli. Gefinn er upp fjöldi og \% ísviga.

\begin{tabular}{lc}
\hline Vefjaflokkur & Fjöldi (\%) \\
\hline Sáðfrumukrabbamein & $\mathbf{4 8}(\mathbf{4 9 , 5 )}$ \\
\hline Ekki-sáðfrumukrabbamein & $\mathbf{4 9}(\mathbf{5 0 , 5 )}$ \\
\hline Blönduð æxli & $32(33,0)$ \\
\hline Fósturvísisæxli (embryonal carcinoma) & $11(11,3)$ \\
\hline Frumkímsæxli (teratoma) & $6(6,2)$ \\
\hline ÆEðabelgsæxli (choriocarcinoma) & $0(0)$ \\
\hline Blómbelgsæxli (yolk sac tumour) & $0(0)$ \\
\hline Alls & $97(100)$ \\
\hline
\end{tabular}

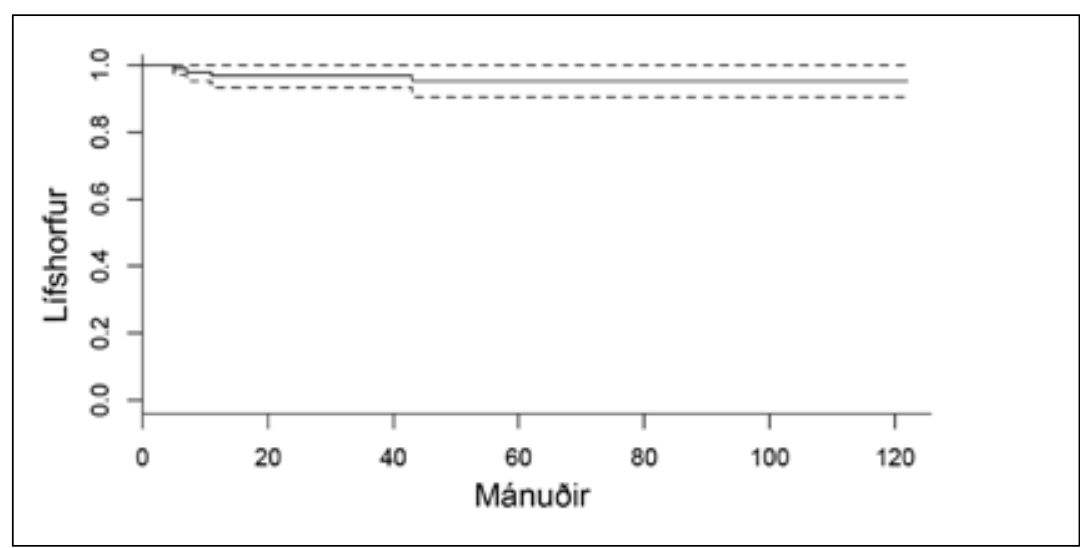

verkir vegna lungnameinvarpa og slappleiki. Hjá fjórum sjúklingum greindist brjóstastækkun (gynecomastia).

Helmingur sjúklinganna $(51,1 \%)$ greindist innan fjögurra vikna, par af 12 innan viku frá upphafi einkenna. Fimmtungur $(20,0 \%)$ sjúklinga hafði haft einkenni í einn til prjá mánuði fyrir greiningu og 17,8\% 1́ meira en hálft ár, par af 11 lengur en eitt ár. Í sjö tilfellum vantaði upplýsingar um tímalengd einkenna.

Allir sjúklingarnir gengust undir aðgerð, yfir-

Mynd 3. Heildarlifshorfur 97 karla sem greindust með eistnakrabbamein á Íslandi 2000-2009. Dann 1. maí 2010 höfðu fjórir sjúklingar látist, par af tveir úr ekkisádfrumukrabbameini en enginn úr sádfrumukrabbameini. Brotnu línurnar sýna 95\% öryggismörk.

Tafla II. Boden-Gibb stigun sjúklinga sem greindust með sáđfrumukrabbamein og ekkisádfrumukrabbbamein á Islandi 2000-2009. Gefinn er upp fjöldi og \% í sviga.

\begin{tabular}{ccccc}
\hline Stig & Lýsing & $\begin{array}{c}\text { Sáðfrumu- } \\
\text { krabbamein }\end{array}$ & $\begin{array}{c}\text { Ekki-sádfrumu- } \\
\text { krabbamein }\end{array}$ & Alls \\
\hline I & $\begin{array}{c}\text { Exli takmarkað við } \\
\text { eista }\end{array}$ & $44(91,7)$ & $\mathrm{n}(\%)$ & $76(78,4)$ \\
\hline IIA & $\begin{array}{c}\text { Meinvörp }<5 \mathrm{~cm} \text { í } \\
\text { aftanskinueitlum }\end{array}$ & $3(6,2)$ & $7(14,3)$ & $10(10,3)$ \\
\hline IIB & $\begin{array}{c}\text { Meinvörp }>5 \mathrm{~cm} \text { í } \\
\text { aftanskinueitlum }\end{array}$ & $1(2,1)$ & $2(4,1)$ & $3(3,1)$ \\
\hline III & $\begin{array}{c}\text { Eitlameinvörp ofan } \\
\text { pindar }\end{array}$ & $0(0)$ & $1(2,0)$ & $1(1,0)$ \\
\hline IV & $\begin{array}{c}\text { Liffærameinvörp utan } \\
\text { eitla }\end{array}$ & $0(0)$ & $7(14,3)$ & $7(7,2)$ \\
\hline Alls & & $48(100)$ & $49(100)$ & $97(100)$ \\
\hline
\end{tabular}




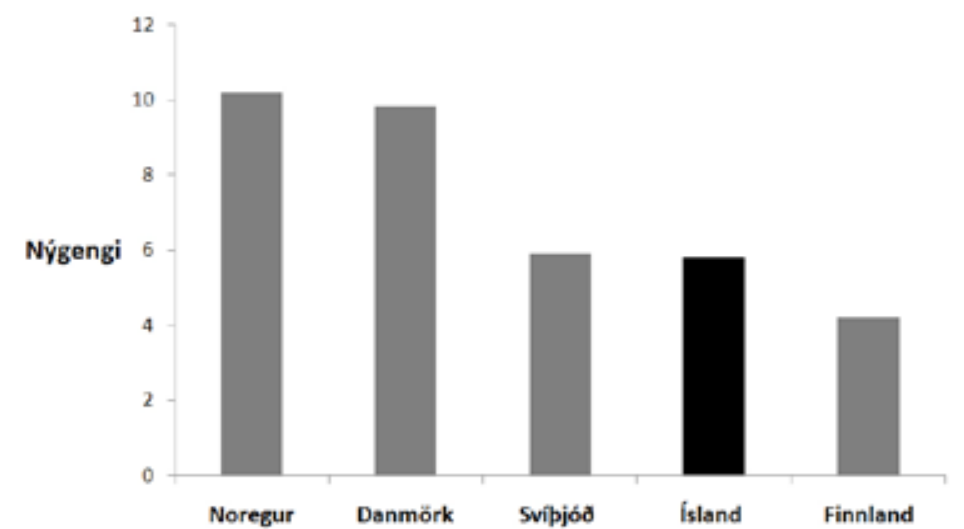

Mynd 4. Aldursstaðlað nýgengi eistnakrabbameins á hverja 100.000 karla á Norðurlöndunum 20002007. Ísland er sýnt med svörtum lit. Upplysingar fengnar úr heimild nr. 3.

leitt í svæfingu, par sem eistað var fjarlægt ásamt kólfi eistans. Farið var í gegnum náraskurð nema í einu tilfelli par sem eistað var fjarlægt í gegnum skurð á pung. Í öðru tilfelli var eista í kviðarholi fjarlægt með kviðarholsspeglun. Aðgerðirnar tóku að meðaltali 44 mínútur (húð til húðar) (bil 20-100). Í 54 aðgerðanna var komið fyrir ígræði úr sílikoni, en hjá tveimur varð að fjarlægja pau, hjá öðrum vegna sýkingar og hjá hinum vegna verkja sem raktir voru til örvefsstrengs.

Í töflu I eru sýndar vefjagerðir æxlanna. Priðjungur E-SFK æxlanna voru blandæxli (33,0\%) og voru fósturvísisæxli (embryonal carcinoma) og frumkímsæxli (teratoma) algengust, bæði í blönduðu æxlunum $(87,5$ og $75,0 \%)$ og peim sem voru af einni vefjagerð $(11,3$ og 6,2\%).

Meðalstærð æxlanna var 4,0 $\pm 2,1 \mathrm{~cm}$, en minnsta æxlið reyndist $0,7 \mathrm{~cm}$ og pað stærsta 10,0 $\mathrm{cm}$. Hvorki fannst marktækur munur á stærð né vefjagerð á fyrra og seinna tímabili rannsóknar. Í 12 æxlum greindist æðaíferð, par af voru níu af ekki-sáðfrumugerð $(\mathrm{p}=0,12)$.

Við greiningu hafði 21 sjúklingur meinvörp og voru pau oftast staðsett í aftanskinueitlum, eða hjá 19 peirra. Enginn pessara sjúklinga purfti skurðaðgerð á aftskinurými við greiningu en sjö sjúklingar með E-SFK (öll með frumkímisæxlispætti) fóru í slíka aðgerð síðar

Tafla III. Boden-Gibb stigun sjúklinga með eistnakrabbameini á Íslandi frá 1970 til 2009. Borin eru saman tímabilin 1970-1977, 1978-1999 og 2000-2009. Tölur úr fyrstu tveimur tímabilunum eru fengnar úr heimild nr. 9. Gefinn er upp fjöldi og \% i sviga.

\begin{tabular}{lccc}
\hline & $\mathbf{1 9 7 0 - 1 9 7 7}$ & $\mathbf{1 9 7 8 - 1 9 9 9}$ & $\mathbf{2 0 0 0 - 2 0 0 9}$ \\
\hline Stig & $\mathrm{n}(\%)$ & $\mathrm{n}(\%)$ & $\mathrm{n}(\%)$ \\
\hline I & $12(52,2)$ & $103(70,5)$ & $76(78,4)$ \\
\hline IIA & $5(21,7)$ & $21(14,4)$ & $10(10,3)$ \\
\hline III & $2(8,7)$ & $10(6,8)$ & $3(3,1)$ \\
\hline IV & $0(0)$ & $4(2,7)$ & $1(1,0)$ \\
\hline Alls & $4(17,4)$ & $8(5,4)$ & $7(7,2)$ \\
\hline
\end{tabular}

vegna síðkominna eða illvígra eitilmeinvarpa. Algengustu fjarmeinvörpin greindust í lungum, eða átta talsins, og tveir sjúklingar greindust auk lungnameinvarpa með heila- og lifrarmeinvörp. Meinvörpin greindust í 17 tilfellum hjá sjúklingum með E-SFK og í fjórum tilfellum af SFK $(80,9 \mathrm{sbr}$. 19,1\%, p=0,005). Enginn sjúklingur með SFK greindist með fjarmeinvörp.

Æxlisvísar voru mældir hjá öllum nema tveimur sjúklingum en pó vantaði upplýsingar um LD hjá 28 (29,5\%) peirra. Hækkun mældist hjá $54(56,8 \%)$ sjúklingum og voru 16 með hreint SFK.

Í töflu II er sýnd Boden-Gibb stigun sjúklinganna, bæði fyrir SFK og E-SFK. Fyrir allan hópinn voru $78,4 \%$ sjúklinga á stigi I, 13,4\% á stigi II og 8,2\% á stigum III-IV. SFK greindust á marktækt lægri stigum samanborið við E-SFK (91,7 sbr. 65,3\% á stigi I; $\mathrm{p}=0,003)$.

Fimm ára heildarlífshorfur fyrir allan hópinn voru 95,1\% (mynd 3). Fjórir sjúklingar létust á rannsóknartímabilinu, par af tveir úr eistnakrabbameini, sem í báðum tilfellum voru af ekki-sáðfrumugerð. Báðir sjúklingarnir voru komnir með meinvörp í lungu, heila og lifur við greiningu. Hinir tveir létust af óskyldum orsökum, annar úr kransæðasjúkdómi en hinn úr ristilkrabbameini. Sjúkdómasértækar lífshorfur mældust 97,8\% fyrir allan hópinn, 100,0\% á stigi I-II og 75,0\% á stigi III-IV (p=0,0001).

\section{Umræða}

Nýgengi eistnakrabbameins mældist 5,9 á hverja 100.000 karla á rannsóknartímabilinu, sem er svipað og tvo áratugina par á undan. ${ }^{9}$ Greinileg aukning sást á áttunda og níunda áratugnum (mynd 3) en 1990-1994 fór nýgengið hæst í 6,6/100.000 karla en hefur lítið breyst síðan. Á mynd 4 sjást nýgengistölur frá hinum Norðurlöndunum á árunum frá 2000 til 2007. Nýgengi eistnakrabbameins á Ísland er svipað og í Svípjóð en í Noregi og Danmörku er nýgengi hærra. Hér á landi og í Danmörku hefur nýgengi sjúkdómsins haldist stöðugt en í Svípjóð og Noregi er sjúkdómurinn enn vaxandi. ${ }^{3}$ Nýgengi er einnig breytilegt á milli svæða, til dæmis er sjúkdómurinn mun sjaldséðari í S-Svípjóð en hinum megin við Eyrarsundið á Kaupmannarhafnarsvæðinu. ${ }^{3,} 15$ Flest bendir pví til pess að umhverfispættir og breytingar á lífsstíl komi við sögu í meingerð eistnakrabbameins, án pess pó að pessir pættir séu pekktir. ${ }^{6}$ Í pessari rannsókn komu pekktir áhættupættir eins og launeista og fjölskyldusaga sjaldan fyrir, eða í 8\% og 1\% tilfella. Í öðrum rannsóknum hefur verið sýnt fram á vægi fjölskyldusögu 
og erfðabreytileika á stutta armi litnings 12, meðal annars í fjölskyldum hér á landi. ${ }^{16}$ Pó virðist sem erfðir skýri ekki nema hluta tilfella, að minnsta kosti eru tengsl eistnakrabbameins við erfðir oft óljós. ${ }^{17}$ Af ofanskráðu er ljóst að munur á nýgengi milli landa og innan samfélaga skýrist sennilega af umhverfispáttum og mismunandi lífsstíl. Einnig bendir margt til pess að erfðir geti skýrt mismunandi næmi manna fyrir peim umhverfispáttum sem eiga pátt í tilurð sjúkdómsins., ${ }^{418}$

Hérlendis sást tilhneiging til vaxandi fjölda E-SFK en munurinn reyndist pó ekki marktækur. Hér á landi hafa SFK lengst af verið fleiri en E-SFK (55 sbr. $45 \%) .{ }^{10}$ Erlendis hefur sést svipuð skipting á milli vefjagerða. ${ }^{15,19}$

Meðalaldur sjúklinga við greiningu var 35,6 ár en sjúklingar með SFK voru að meðaltali 11,5 árum eldri við greiningu samanborið við sjúklinga með E-SFK. Svipaðar niðurstöður hafa sést í erlendum og eldri íslenskum rannsóknum. 9, 10, 20

Um 78\% sjúklinganna greindust á stigi I og voru pví með sjúkdóm sem bundinn var við eistað. Í erlendum rannsóknum er petta hlutfall sambærilegt, eða á bilinu 69 - 70\%.20-22 Eins og sést í töflu III jókst hlutfall sjúklinga á stigi I frá 1978 (71\%) og enn meira ef miðað er við tímabilið frá 1970 til 1977, en pá greindust 52\% sjúklinga á stigi I. Hlutfall sjúklinga á stigi I hefur pó ekki breyst marktækt síðustu prjá áratugi.

SFK greindust á marktækt lægri stigum samanborið við E-SFK (91,7 sbr. 65,3\% á stigi I, $\mathrm{p}<0,0001)$. Ennfremur greindist enginn sjúklingur með SFK með fjarmeinvörp en átta sjúklingar með E-SFK. Fyrrnefndu meinin virðast pví ekki eins illvíg og sjúkdómasértækar fimm ára lífshorfur voru $100 \%$, eða ívið hærri en fyrir E-SFK sem voru $92 \%$. Pessi munur var pó ekki marktækur frekar en í eldri rannsókn okkar sem náði til 198 sjúklinga. ${ }^{10}$ Erlendis hefur pó verið sýnt fram á betri lífshorfur sjúklinga með SFK samanborið við E-SFK. ${ }^{23}$

Alls voru 95,1\% sjúklinga á lífi fimm árum frá greiningu, sem verður að teljast mjög góður árangur en í erlendum rannsóknum eru lífshorfur yfirleitt á bilinu $83-93 \%{ }^{24}$. Til samanburðar voru fimm ára lífshorfur hér á landi á tímabilinu 1955-1977 67\% en hækkuðu í 96\% árin 1978-1999. Var aukningin skýrð með tilkomu cisplatínlyfjameðferðar. ${ }^{9}$

Aðeins tveir sjúklingar létust úr sjúkdómnum á pessu 10 ára tímabili, en tveir aðrir létust af óskyldum orsökum. Báðir fyrrnefndu sjúklingarnir höfðu útbreitt E-SFK og voru með meinvörp í lungum, lifur og heila (stig IV) við greiningu. Pessir sjúklingar svöruðu illa staðlaðri lyfjameðferð (bleómýsín, etópósíð og cisplatínum) og annar peirra fékk geislameðferð á heila án teljandi svörunar. Meinvörp í heila eru oft erfið viðfangs par sem lyfin berast illa yfir heilablóðpröskuldinn. ${ }^{25}$ Bæta má lífslíkur pessara sjúklinga með háskammta lyfjameðferð sem inniheldur platiníum og geislameðferð á heila. ${ }^{11}$

Langflestir greindust vegna fyrirferðar í eista (94,8\%). Var rúmlega helmingur peirra án verkja en margir peirra virtust draga að leita til læknis. Hins vegar greindist helmingur sjúklinganna innan mánaðar og rúmlega 13\% greindust innan viku frá upphafi einkenna. Til samanburðar greindust aðeins 3\% sjúklinganna innan viku frá upphafi einkenna í íslenskri rannsókn sem tók til áranna $1955-1999 .{ }^{9}$ Erfitt er að fullyrða að tími frá einkennum til greiningar hafi styst á peim áratugum sem rannsóknirnar náou til en hafa verður í huga að pær voru allar afturskyggnar og pví að einhverju leyti ónákvæmar hvað varðar mat á tímalengd einkenna.

Allir sjúklingar nema einn gengust undir ómskoðun á eista, og töku tölvusneiðmynda af kviðarholi og aftanskinurými. Báðar pessar rannsóknir eru hluti af uppvinnslu pessara sjúklinga $^{8}$ og sama á við um mælingu á æxlisvísunum AFP, $\beta$-hCG og LD. ${ }^{26}$ Alls reyndist einhver pessara æxlisvísa hækkaður hjá 54 sjúklingum $(56,8 \%)$, og voru 16 peirra með hreint SFK. Athyglisvert er að upplýsingar um LD vantaði hjá 28 sjúklingum $(29,5 \%)$ en $L D$ getur verið eini æxlisvísirinn sem er hækkaður í sáðfrumukrabbameini og er ekki síður mikilvægur en AFP og $\beta$-hCG í greiningu og við mat á svörun meðferðar. ${ }^{26}$ Æxlisvísar eru einnig mikilvægur hluti TNM-stigunarkerfisins. ${ }^{27}$ Eins og áður kom fram stiguðum við sjúklingana eftir bæði BodenGibb og TNM-kerfi, aðallega til að auðvelda samanburð við eldri rannsóknir.

Nýgengi eistnakrabbameins á Íslandi er í meðallagi miðað við nágrannalönd og hefur haldist tiltölulega stöðugt síðustu tvo áratugi. Á sama tímabili hefur hlutfall sjúklinga með staðbundinn sjúkdóm (stig I) lítið breyst og stærð æxlanna sömuleiðis. Lífshorfur íslenskra karlmanna með eistnakrabbamein eru mjög góðar og með pví hæsta sem pekkist.

\section{Pakkir}

Pakkir fá Gunnhildur Jóhannesdóttir skrifstofustjóri fyrir hjálp við öflun sjúkraskráa og Martin Ingi Sigurðsson læknir fyrir hjálp við tölfræðiúrvinnslu. 


\section{Heimildir}

1. Huyghe E, Matsuda T, Thonneau P. Increasing incidence of testicular cancer worldwide: a review. J Urol 2003; 170: 5-11.

2. www.krabbameinsskra.is

3. www-dep.iarc.fr

4. Dieckmann KP, Pichlmeier U. Clinical epidemiology of testicular germ cell tumors. World J Urol 2004; 22: 2-14.

5. McGlynn KA, Devesa SS, Graubard BI, Castle PE. Increasing incidence of testicular germ cell tumors among black men in the United States. J Clin Oncol 2005; 23: 5757-61.

6. Schmiedel S, Schuz J, Skakkebaek NE, Johansen C. Testicular Germ Cell Cancer Incidence in an Immigration Perspective, Denmark, 1978 to 2003. J Urol 2010; 183: 1378-82.

7. Tseng A Jr, Horning SJ, Freiha FS, Resser KJ, Hannigan JF Jr, Torti FM. Gynecomastia in testicular cancer patients Prognostic and therapeutic implications. Cancer 1985; 56 2534-8.

8. Shaw J. Diagnosis and treatment of testicular cancer. Am Fam Physician 2008; 77: 469-74

9. Gudbjartsson T, Magnusson K, Bergthorsson J, et al. A population-based analysis of increased incidence and improved survival of testicular cancer patients in Iceland. Scand J Urol Nephrol 2003; 37: 292-8.

10. Agnarsson BA, Gudbjartsson T, Einarsson GV, et al Testicular germ cell tumours in Iceland: a nationwide clinicopathological study. APMIS 2006; 114: 779-83.

11. Shintaku I, Satoh M, Okajima E, et al. Survival of metastatic germ cell cancer patients assessed by international germ cel consensus classification in Japan. Jpn J Clin Oncol 2008; 38 : 281-7.

12. Guðbjartsson T, Björnsson R, Magnússon K, Björnsson $S$ Einarsson GV. Góðar lífshorfur karla með sáðkrabbamein: afturskyggn rannsókn á íslenskum körlum greindum 19711990. Læknablaðið 1996; 82: 202-8.

13. Björnsson R, Guðbjartsson T, Magnússon K, Guðlaugsson EG, Björnsson S, Einarsson GV. Frjófrumuæxli í eistum önnur en sáðkrabbamein: gerbreyttar horfur: afturskyggn rannsókn á Íslandi 1971-1995. Læknablaðið 1997; 7: 477-85.

14. Boden G, Gibb R. Radiotherapy and testicular neoplasms. Lancet 1951; 2: 1195-7.

15. Richiardi L, Bellocco R, Adami HO, et al. Testicular cancer incidence in eight northern European countries: secular and recent trends. Cancer Epidemiol Biomarkers Prev 2004; 13: 2157-66.
16. Bergthorsson JT, Agnarsson BA, Gudbjartsson T, et al. A genome-wide study of allelic imbalance in human testicular germ cell tumors using microsatellite markers. Cancer Genet Cytogenet 2006; 164: 1-9.

17. Dong C, Hemminki K. Modification of cancer risks in offspring by sibling and parental cancers from 2,112,616 nuclear families. Int J Cancer 2001; 92: 144-50.

18. Starr JR, Chen C, Doody DR, et al. Risk of testicular germ cell cancer in relation to variation in maternal and offspring cytochrome p450 genes involved in catechol estrogen metabolism. Cancer Epidemiol Biomarkers Prev 2005; 14: 2183-90.

19. Chia VM, Quraishi SM, Devesa SS, Purdue MP, Cook MB, McGlynn KA. International trends in the incidence of testicular cancer, 1973-2002. Cancer Epidemiol Biomarkers Prev; 19: 1151-9.

20. Osswald M, Harlan LC, Penson D, Stevens JL, Clegg LX. Treatment of a population based sample of men diagnosed with testicular cancer in the United States. Urol Oncol 2009; 27: 604-10.

21. Oldenburg J, Lehne G, Fossa SD. Testikkelkreft. Tidsskr Nor Laegeforen 2008; 128: 457-60.

22. Sundstrom J, Salminen E, Nurmi M, et al. Management of testicular cancer - 16 years' experience from southwest Finland. Scand J Urol Nephrol 2001; 35: 21-5.

23. Oshima A, Kitagawa $\mathrm{T}$, Ajiki W, Tsukuma $\mathrm{H}$, Takenaka $\mathrm{S}$, Iura A. Survival of testicular cancer patients in Osaka, Japan. Jpn J Clin Oncol 2001; 31: 438-43.

24. Aareleid T, Sant M, Hedelin G. Improved survival for patients with testicular cancer in Europe since 1978. Eur J Cancer 1998; 34: 2236-40.

25. Bokemeyer C, Nowak P, Haupt A, et al. Treatment of brain metastases in patients with testicular cancer. J Clin Oncol 1997; 15: 1449-54.

26. Stenman UH. Testicular cancer: the perfect paradigm for marker combinations. Scand J Clin Lab Invest 2005; 65: 181-8.

27. Union for International Cancer Control. 6th ed. Wiley-Liss, New York 2002.

\section{Testicular cancer in Iceland 2000-2009: Incidence and survival}

Introduction: Survival of patients with testicular germ cell tumours has improved in recent years, mainly due to new modes of chemotherapy. We analyzed incidence, staging and survival of patients diagnosed during the last ten years in Iceland and compared the results to previous studies.

Materials and methods: A retrospective study including all Icelandic males diagnosed during 2000-2009.

Pathology reports were reviewed and the tumours staged (Boden-Gibb). Overall survival was estimated and seminomas (ST) and non-seminomas (N-ST) compared. Results: 97 males were diagnosed, age-adjusted incidence being 5.9/100.000 males per year. The number of ST and N-ST was almost equal, and the mean age was 35.6 (range; 15-36), but patients with ST were 11.5 years older compared to N-ST. Symptoms were similar in both groups, also tumor size $(4.0 \mathrm{~cm})$, which did not change during the study period. Most of the tumours were in stage I, or $78.4 \%, 13.4 \%$ were in stage II og $8.2 \%$ in stage III-IV. ST were diagnosed at a significantly lower stage compared to N-ST (91.7 versus $65.3 \%$ in stage I; $p=0.003$ ). No distant metastases were diagnosed in patients with ST but in 8 patients with N-ST. Four patients died during the study period, two due to N-ST but no patient died because of ST. Five-year survival for the whole patient group was $95.1 \%$.

Conclusion: The incidence of testicular carcinoma in Iceland is similar to neighbouring countries and has remained fairly constant for the last two decades. At the same time the number of patients with localized disease (stage I) as well as the size of the tumours has not changed significantly. Survival in Iceland is comparable to the best results reported elsewhere.

Orrason AW, Agnarsson BA, Geirsson G, Helgason HH, Gudbjartsson

Testicular cancer in Iceland 2000-2009: Incidence and survival /cel Med J 2011; 97: 143-8

Correspondence: Tómas Guðbjartsson, tomasgud@landspitali.is

Key words: Testicular germ cell tumours, seminoma, non-seminoma, incidence, survival, treatment. 